\title{
INFLUENCE OF SOCIAL RESPONSIBILITY ON IMPLEMENTATION OF SUSTAINABLE SUPPLY CHAIN IN SELECTED ENERGYCOMPANIES IN POLAND
}

\begin{abstract}
The article presents the importance of the concept of sustainable development and the concept of Corporate Social Responsibility (CSR) on the functioning of the supply chain in organizations. The relationship between socially responsible business and sustainable development has also been noticed, as is also emphasized by many international documents, including the ISO 26000 standard, which is a guide for organizations wishing to implement these concepts into their functioning. The principles of social responsibility, like the concept of sustainable development from which they originate, emphasize the balance between the economic, social and ethical sphere of business activity. Necessary for proper and sustainable supply chain management is also the identification of all stakeholder groups with which the organization interacts and the company's policy, which creates a responsible organizational culture. Enterprises that try to operate in a socially responsible manner also pay attention to the principles of running business by all stakeholders with whom they cooperate, which is why the requirements towards them are increasingly increasing. The responsibility of the entire supply chain and the implementation of a sustainable supply chain is becoming more and more popular for contemporary enterprises, thanks to which organizations gain additional long-term benefits and, as a result, they provide a competitive advantage. The article also shows how the concept of social responsibility can become the basis for creating and implementing a sustainable supply chain in the organization and how these sustainable chains function on selected examples of energy companies in our country.
\end{abstract}

Keywords: social responsibility, sustainable development, CSR strategy.

\section{INTRODUCTION}

The subject of corporate social responsibility (CSR) is of particular importance in the context of sustainable development. This concept is growing rapidly and is becoming increasingly popular. More and more we deal with a situation when the value of a product is perceived by the value of a brand, which is often created by customers and other stakeholders. The value of the product determines its quality, but also subjective feelings of consumers, which affects the functioning of the company and its behavior in the market. This can cause some criticism that affects changes in the functioning of the corporate entity, especially the increasing demands of stakeholders and their attitude to socially responsible activities in all the supply chain.

\footnotetext{
${ }^{1}$ Dr Jolanta Stec-Rusiecka, Katedra Przedsiębiorczości, Zarządzania i Ekoinnowacyjności, Wydział
} Zarządzania, Politechnika Rzeszowska, autor korespondencyjny; e-mail: rusiecka@ prz.edu.pl. 
The main aim of the article is to illustrate what values the organization brings to implement a sustainable supply chain. The concept of CSR should become the basis for a sustainable supply chain. Such an action could bring the company long-term benefits, mainly related to the development of a positive relationship with stakeholders and strengthening its competitive advantage.

\section{THEORY OF SUSTAINABLE DEVELOPMENT AND ITS IMPACT ON SUPPLY CHAIN}

The theory of sustainable development derives from the theory of the environment, and its purpose was to protect the environment related to the efficient use of natural resources ${ }^{2}$. In theory one assumed "that a man must consume limited resources in a rational manner, guaranteeing social security and allowing their exploitation for generations" 3 .

The criticism of excessive exploitation of natural environment has contributed to the creation of the theory of sustainable development, the unsustainable use of natural resources, and the degradation and disturbance of the global eco-system.

Sustainable development "is the socio-economic development where the process of integration of political, economic and social activities occurs, while maintaining natural balance and permanence of basic natural processes in order to guarantee the possibility of satisfying the basic needs of individual communities or citizens of the modern and future generations".

As shown in figure 1, sustainable development has three main objectives: ecology, economy and society.

The idea of sustainable development does not negate the growth of prosperity, it only emphasizes the need to balance all the elements: economic, social and environmental ones. This concept requires the support of the economy in the following areas ${ }^{5}$ : economic (manifesting with the desire for economic growth), environmental (expressed by efforts to protect the environment) and social (leading to improve the quality of life).

Referring the concept of sustainable development to the concept of social responsibility it needs to be emphasized that CSR is often considered as a business response to the challenges of sustainable development. The World Business Council for Sustainable Development - WBCSD defines corporate social responsibility as "business activity contributing to sustainable economic development, focused on working with employees, their families, local community and all society to improve the quality of their lives"6.

\footnotetext{
2 J. Zwoździak, Ł. Szałata, M. Fortuna, Promowanie idei zrównoważonego ekorozwoju miast niskoweglowych na wybranych przykładach [in:] Marketing przyszłości. Trendy. Strategie. Instrumenty. Wybrane aspekty marketingu terytorialnego, ed. A. Smalec, Zeszyty Naukowe Uniwersytetu Szczecińskiego, no. 663 (75/2011), Szczecin 2011, p. 258.

3 Ibidem, p. 258.

4 JOL 2001 No. 62, item. 627 ACT of 27 April 2001 Environmental Protection Law (Prawo ochrony środowiska), art. 3.

${ }^{5}$ M. Rybak, Etyka menedżera - społeczna odpowiedzialność przedsiębiorstwa, Warszawa 2004, p. 204.

6 D. Teneta-Skwiercz, Uwarunkowana realizacji koncepcji spotecznej odpowiedzialności biznesu w przedsiębiorstwach polskich na tle doświadczeń Wielkiej Brytanii i Niemiec, Wrocław 2013, p. 40.
} 


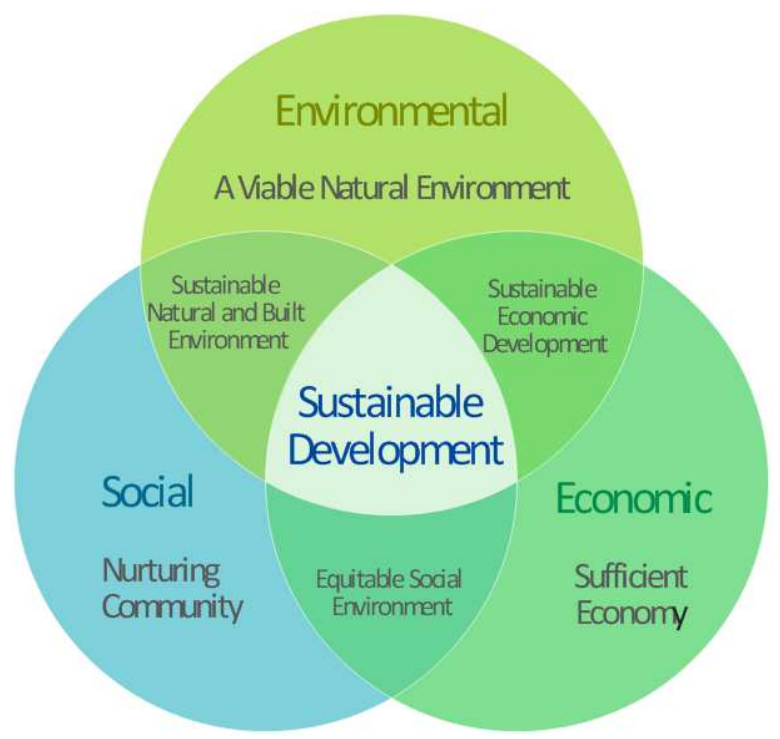

Figure 1. Triangle of sustainable development objectives

Own: Own research based upon J. Zwoździak, Ł. Szałata, M. Fortuna, Promowanie idei zrównoważonego ekorozwoju..., p. 257.

In response to the challenges of sustainable development concept, entrepreneurs can implement CSR. Depending on the stage of implementation of the social responsibility concept, the effects of this implementation may be different (they may, among other things determine the most efficient way of using resources, which brings benefits for both the organization and its environment) ${ }^{7}$.

\section{THE CONCEPT OF SOCIAL RESPONSIBILITY AS THE BASIS OF CREATING SUSTAINABLE SUPPLY CHAIN}

The development of social responsibility is the result of social demand for the new role of enterprises. Apart from generating profits they should also create the ethical, social and environmental values. Socially involved business should take over responsibility for social development, give up socially harmful effects, supply goods and services also in unprofitable areas.

In the nowadays meaning the concept of CSR includes the following elements:

- "fulfillment of the obligations to the different groups of stakeholders,

- responding to social needs and expectations",

- the use of social responsibility as a tool for business management ${ }^{8}$.

This definition emphasizes the influence of stakeholders to take socially responsible activities by companies.

7 J. Graafland, B. van de Ven, Strategic and moral motivation for corporate social responsibility, Journal of Corporate Citizenship 22 (2006), pp.111-123.

${ }^{8}$ D. Teneta-Skwiercz, Uwarunkowana realizacji..., p. 26. 
According to the ISO 26000 standard Guidance on Social Responsibility ${ }^{9}$ social responsibility of businesses is the responsibility of organizations for the impact of undertaken actions and decisions on society and the environment. It manifests in a transparent and ethical behavior that:

- "contributes to sustainable development, including the health and welfare of society,

- takes into account the expectations of stakeholders

- complies with applicable law and consistent with international norms of behavior,

- is integrated with the organization and practiced in its relationships"10.

Corporate social responsibility is based on the assumption that enterprises are economically, legally ansd socially responsible for their activities ${ }^{11}$. They aim not only to bring profit to the shareholders (owners), but voluntarily take actions to improve the lives of stakeholders and environmental cleanliness. They are aware of the existence of responsible behavior with a stable business success.

Social responsibility is also understood as an innovative strategy for building a good business relationship with the environment, which is reflected in its economic success ${ }^{12}$. B. Rok emphasizes that the essence of this concept is its interdisciplinarity ${ }^{13}$.

J. Korpus ${ }^{14}$ considers CSR as an effective management strategy, which contributes to an innovative way of building a competitive advantage of an enterprise in the market. The same approach to this issue have M.E. Porter and M.R. Kramer ${ }^{15}$, and emphasize the realtionship of corporate social responsibility with a positive impact on economic situation of an enterprise. Definitions of this type stress that CSR $^{16}$ :

- is a part of the company strategy, and through the optimal use of resources it enables its sustainable development;

- contributes to the market success of the company by building positive relationships with the environment and competing non-economic factors;

- can be regarded as an effective impact on the environment - takes care of stakeholders; generates loyalty (favor) of potential customers.

The elements influence on the social policy formulation in companies, many different factors that determine the formulation of the strategy of social responsibility influence on the enterprises. In turn, the selected strategy results in different ways of responding to social

9 Compare: Norm BS ISO 26000:2010, Guidance on social resposibility, BSI 2010.

10 J. Krasodomska, Spoteczna odpowiedzialność w praktyce polskich przedsiębiorstw i ksztatceniu studentów [in:] Społeczna odpowiedzialność organizacji. Polityczna poprawność czy obywatelska postawa? ed. Z. Pisz, M. Rojek-Nowosielska, Prace Naukowe Uniwersytetu Ekonomicznego we Wrocławiu No. 220, Wyd. UE we Wrocławiu, Wrocław 2011, pp. 166-167.

${ }^{11}$ G. Bartkowiak, Społeczna odpowiedzialność biznesu w aspekcie teoretycznym i empirycznym, Warszawa 2011, pp. 9-16.

12 B. Rok (red.), Więcej niż zysk, czyli odpowiedzialny biznes. Programy, strategie, standardy, Warszawa 2001, s. 32.

${ }^{13}$ B. Rok, Społeczna odpowiedzialność biznesu [w:] Biznes, etyka, odpowiedzialność, red. W. Gasparski, Warszawa 2012, s. 423-432.

14 J. Korpus, Spoteczna odpowiedzialność przedsiębiorstw $w$ obszarze ksztattowania środowiska pracy, Warszawa 2006, p. 9.

15 M.E. Porter, M.R. Kramer, The competitive advantage of corporation philanthropy, "Harvard Business Review", Vol. 80(2002) No. 12, pp. 57-68.

16 J. Nakonieczna, Społeczna odpowiedzialność przedsiębiorstw międzynarodowych, Warszawa 2008, p. 20. 
pressures. A common reaction is inaction, but it may also be the reactivity, proactivity and interactivity. Enterprises should respect the principles of social responsibility throughout the supply chain. Corporate social responsibility should be a part of corporate management and daily practice.

According to the social responsibility in the supply chain, products should be produced, delivered, consumed and disposed of in order to reduce energy consumption and reduce $\mathrm{CO}_{2}$ emissions. Socially responsible supply chain should enable to achieve social and environmental benefits by all participants ${ }^{17}$.

The quest for a sustainable supply chain results from the needs of the contemporary world and contributes to improve the image, multiply profits, and achieve competitive advantage.

Effective management of a sustainable supply chain means the integration of socio-environmental process of supply chain management. Therefore, it can be defined as the management of material and information flow along the entire value chain, taking into account the elements of sustainable development suggested by stakeholders.

The development of a socially responsible, sustainable and stable supply chain is possible only when we choose the appropriate partners, and in the honest manner will participate in the implementation of socio-environmental objectives.

\section{SOCIAL RESPONSIBILITY AND SUSTAINABLE SUPPLY CHAIN ON SOME EXAMPLES OF ENERGY ENTERPRISES IN POLAND}

Energy is considered to be one of the key pillars of the modern economy, and global challenges related to ensuring of the safety of the energy market and its efficiency is a constant subject of international discussions. Electricity and gas fuels allow economic development, and thus have a significant impact on social development. Unique products, the size of turnovers and influence on the environment mean that energy companies in the significant manner contribute to the determination of ethical standards in business. The factors resulting in the introduction of the principles of social responsibility in the energy sector include: improving the efficiency, reducing the impact on the environment, the requirements of customers and the local community, working with central and local authorities and industrial change. Awareness of the impact on the environment, the use of the principle of transparency and the use of information technology affects positively the development of the organization and increase its value. As social criteria increasingly affect the business activities of legitimacy, the implementation of CSR principles is reasonable . By incorporating social activities to strategies of energy companies, their brand recognition and customer loyalty improve ${ }^{18}$.

Corporate social responsibility is the contribution of business to a state's energy policy. Thanks to CSR organizations do not take their advantage to con-counterparties, customers

${ }^{17}$ D. Kisperska-Moroń, Społeczna odpowiedzialność tańcuchów dostaw i ich systemów logistycznych (założenia koncepcyjne), „Logistyka”, nr 4, ILiM, Poznań 2012, p. 375.

18 A. Herbuś, Spoteczna odpowiedzialność biznesu w energetyce. Przedsiębiorstwa energetyczne spotecznie odpowiedzialne. A report within the FEWE project "Improvement of the level of education in local governments in the field of sustainable energy management and protection of the Earth's climate", http://www.energiaisrodowisko.pl, pp. 1-3. 
and consumers of electricity or gas, and the rules they are guided by are: transparency, openness and honesty ${ }^{19}$.

As research shows, the interest of the energy sector in the subject of social responsibility continues to grow ${ }^{20}$. Among the 29 entities surveyed, $93 \%$ of energy companies declare that the subject of CSR is discussed at meetings of the board. As for the inclusion of the principles of social responsibility to the strategy of the organization, $82 \%$ of the respondents answered that CSR was taken into account for strategic purposes, $7 \%$ showed their lack, and $11 \%$ respondents say that it is in the company plans. The greatest progress in the recognition of the principles and objectives of social business strategy can be seen in the gas industry all companies reported that they had CSR in their strategies ${ }^{21}$.

Studies indicate that $86 \%$ of energy companies have implemented so far various types of management procedures (and 7\% plan to introduce them) related to social responsibility, among others, environmental management systems (ISO 14001), quality, risk and procedures for charitable activities, codes of ethics ${ }^{22}$.

Good examples which illustrate a responsible approach to business in the energy sector are the Polish Oil and Gas Company (PGNiG) and the Polish Energy Group (PGE) therefore they will be discussed later in the article.

Polish Oil and Gas Company (PGNiG) S.A. is the largest cooperative in Poland which deals with the exploration, production, storage, distribution and sale of natural gas. In pursuing its activities, PGNiG does not forget about social and environmental issues. In 2009, with the cooperation of the workers "The Strategy for Sustainable Development and Responsible Business of the PGNiG Group" was developed, which complements the business strategy of the company. PGNiG pursues its objectives taking into account the needs of all stakeholders, and foremost among them there are: employees, communities and customers.

"The Strategy for Sustainable Development and Responsible Business of the PGNiG Group" defines six key business areas:

- natural environment protection,

- customer care (increasing the quality current services and future customers),

- creating a safe and friendly workplace,

- cooperation with social partners and business based on trust and openness,

- search for new areas of business,

- effective communication and marketing ${ }^{23}$.

The activities implemented by PGNiG can be divided into four categories:

- market / client,

- society / local communities,

- environment,

- employees ${ }^{24}$.

\footnotetext{
${ }^{19}$ Report: Społeczna odpowiedzialność przedsiębiorstw energetycznych, „Biuletyn URE” 2011, No. 3(77), p. 19

${ }^{20}$ Ibidem, pp. 19-35.

${ }^{21}$ Ibidem, pp. 19-35.

22 Ibidem, pp. 19-35.

${ }^{23}$ Social report GK PGNiG 2014, Odpowiedzialna energia, p. 18.

${ }^{24}$ Ibidem, p. 18.
} 
PGNiG Group strives to be a modern and should be efficiently managed in the wholevalue chain in the gas, fuel and electro-energy sector. The group consists of companies with different profiles, occupying particular chain cells. The companies included in the PGNiG Group work within four key segments: exploration and production, trading and storage, distribution and manufacturing. Diversified business structure affects the diversity of the supply chain. Each of the companies of the PGNiG Group is guided by its own policy regarding suppliers. PGNiG cooperates with about 60 thousand suppliers mainly Polish ones, but also from the USA, Singapore, China, Japan, Canada and Russia ${ }^{25}$.

The PGNiG Group, aware of the challenges it faces, is involved in the Global Compact initiative, so in the whole group the human rights are respected and provided proper labor standards, the environment is protected and the corruption is fought over. Active reduction on the environmental impact is realized through investments limiting greenhouse gas emissions and air pollution, providing safety of soils and groundwater, as well as the reduction of waste. Pro-environment activities in the group, among others, include: reconstruction of boilers, modernization of wet flue gas desulfurization, development of filters to the boilers and flue gas monitoring, modernization of furnace waste gas disposal and linitation of noise emission in the environment ${ }^{26}$.

The PGNiG Group carried out activities are also aimed at current and future employees and their families, this is mainly to support social and living conditions, including: organization and recreation funding, financial assistance and support for families in the most difficult situation, financial assistance for housing, organization and financing of active recreation and subsidizing of non-public medical care ${ }^{27}$.

The goal of PGNiG of effective, based on the principles of partnership and dialogue cooperation with social partners is implemented by the actions related to, among others, local identification of needs and expectations of the community (meetings with the authorities and inhabitants of municipalities). Good neighborhood is being built by: support of schools, building roads, sponsorship of major events in the municipality and responsibility for the preservation of social and cultural outstanding values of specific regions ${ }^{28}$.

The second group subjected to analysis is Polish Energy Group (PGE), which is Poland's largest group of power sector and the largest producer and the key supplier of electricity for households and companies in the country. PGE Group is present in the entire value chain of energy starting from extraction, through the production, sale and distribution. The activity of GK PGE is organized according to in five segments: conventional energy, renewable energy, wholesale, distribution and retail ${ }^{29}$.

In 2014, the Code of PGE Group was adopted, which enables the efficient and effective management and the commitment of all companies in the group to act in its interests and realization of the group strategy. In 2011, the Code of Ethics was developed, which is a set of principles and valuesrespected by the Management Board and employees, i.e.: the rule of law, transparency, integrity, professionalism, honesty, loyalty and tolerance ${ }^{30}$.

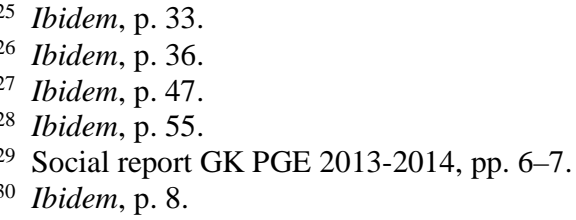


PGE Capital Group is aware of its impact on the environment, so in a planned way manages every area of its business. In 2014 there were developed (in consultation with internal stakeholders) the rules on the social responsibility management. The team for CSR aims to create a coherent action in the field of social responsibility in the whole the group, creation and implementation of programs to promote this idea and undertaking internal and external communication activities. Since 2008 PGE Group has been participating in the Global Compact initiative. In 2014, the Code of Good Practice was signed which promotes fair competition in the energy market ${ }^{31}$.

PGE Capital Group is based on national fuel resources which generates electricity and delivers it to more than 5 million individual and business customers. It constantly replaces older and less efficient generating units, and it is also investing in distribution network increasing its safety and performance. PGE Capital Group realizes investments crucial for the security of energy supply. Before investing the company examines the scale of its impact on the environment and minimizes its impact on the environment. It also plans to develop the ares after the cessation of its activities. Before investing the dialogue with local communities is conducted, taking into account information about the impact of investment on the environment and its positive aspects (i.a. development of the region, new jobs) ${ }^{32}$.

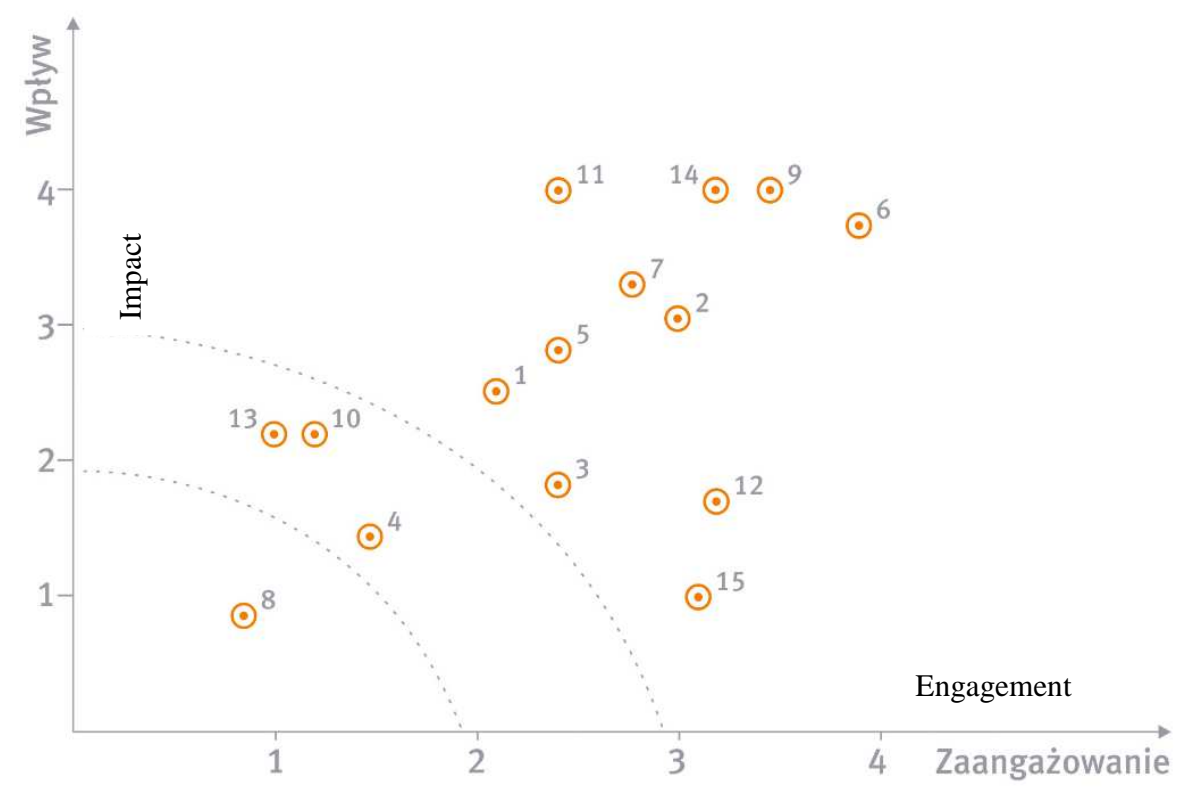

Figure 2. Stakeholders - their engagement and impact on company Social report GK PGE 2013-2014, p. 44.

31 Ibidem, p. 10.

32 Ibidem, pp. 12-13. 
The main stakeholders of the PGE Capital Group include recipients of electricity and heat, and one of the pillars of the business strategy is to improve the quality of their service. In order to achieve the regular surveys on customer satisfaction are conducted ${ }^{33}$.

The development of the organization based on values is possible thanks to the largest capital of the PGE capital Group which are the employees (over 40,000 people). The cmpany pays attantion to ensuring safe and stable working conditions while allowing staff to carry out unique projects ${ }^{34}$.

PGE Capital Group is also a partner for the local community, mainly for self-governments of municipalities. It runs educational activities in the field of safe use of energy and environmental protection ${ }^{35}$.

\section{CONCLUSIONS}

Sustainable supply chain refers to the environmental, social and economic issues and their taking into account in all product life cycle. The identification of all groups of stakeholders and relevant company policy forming the right organization culture, which is also required among the cooperative organizations, are indispensable for proper and sustainable supply chain management. Only thanks to this approach the company may have an impact on the creation of a fully sustainable supply chain and reap the tangible benefits.

\section{REFERENCES}

[1] Bartkowiak G., Społeczna odpowiedzialność biznesu w aspekcie teoretycznym i empirycznym, Wyd. Difin, Warszawa 2011.

[2] Graafland J., van de Ven B., Strategic and moral motivation for corporate social responsibility, Journal of Corporate Citizenship 22 (2006).

[3] Herbuś A., Społeczna odpowiedzialność biznesu w energetyce. Przedsiębiorstwa energetyczne spotecznie odpowiedzialne. A report within the FEWE project "Improvement of the level of education in local governments in the field of sustainable energy management and protection of the Earth's climate'. http://www.energiaisrodowisko.pl.

[4] JOL 2001 No. 62, item. 627 ACT of 27 April 2001 Environmental Protection Law (Prawo ochrony środowiska), art. 3 [Dz. U. 2001 Nr 62 poz. 627 USTAWA z dnia 27 kwietnia 2001 r. Prawo ochrony środowiska, art. 3.]

[5] Kisperska-Moroń D., Społeczna odpowiedzialność łańcuchów dostaw i ich systemów logistycznych (założenia koncepcyjne), ,Logistyka”, nr 4, ILiM, Poznań 2012.

[6] Korpus J., Społeczna odpowiedzialność przedsiębiorstw w obszarze ksztattowania środowiska pracy, Wyd. Placet, Warszawa 2006.

[7] Krasodomska J., Społeczna odpowiedzialność w praktyce polskich przedsiębiorstw i ksztatceniu studentów [in:] Spoteczna odpowiedzialność organizacji. Polityczna poprawność czy obywatelska postawa? ed. Z. Pisz, M. Rojek-Nowosielska, Prace Naukowe Uniwersytetu Ekonomicznego we Wrocławiu no. 220, Wyd. UE we Wrocławiu, Wrocław 2011.

33 Ibidem, p. 25.

34 Ibidem, pp. 32-33.

35 Ibidem, p. 38. 
[8] Nakonieczna J., Społeczna odpowiedzialność przedsiębiorstw międzynarodowych, Wyd. Difin, Warszawa 2008.

[9] Norm BS ISO 26000:2010, Guidance on social resposibility, BSI 2010.

[10] Porter M. E., Kramer M. R., The competitive advantage of corporation philanthropy, "Harvard Business Review", Vol. 80(2002) No. 12.

[11] Report: Społeczna odpowiedzialność przedsiębiorstw energetycznych. „Biuletyn URE” 2011, No. 3(77).

[12] Rok B.(ed.), Więcej niż zysk, czyli odpowiedzialny biznes. Programy, strategie, standardy, Forum Odpowiedzialnego Biznesu, Warszawa 2001.

[13] Rok B., Spoteczna odpowiedzialność biznesu, [w:] Biznes, etyka, odpowiedzialność, ed. W. Gasparski, Wydawnictwa Profesjonalne PWN, Warszawa 2012.

[14] Rybak M., Etyka menedżera - społeczna odpowiedzialność przedsiębiorstwa, PWN, Warszawa 2004.

[15] Social report GK PGE 2013-2014.

[16] Social report GK PGNiG 2014, Odpowiedzialna energia.

[17] Teneta-Skwiercz D., Uwarunkowana realizacji koncepcji społecznej odpowiedzialności biznesu w przedsiębiorstwach polskich na tle doświadczeń Wielkiej Brytanii i Niemiec, Wyd. UE we Wrocławiu, Wrocław 2013.

[18] Zwoździak J., Szałata Ł., Fortuna M., Promowanie idei zrównoważonego ekorozwoju miast niskowęglowych na wybranych przykładach [in:] Marketing przyszłości. Trendy. Strategie. Instrumenty. Wybrane aspekty marketingu terytorialnego, ed. A. Smalec, Zeszyty Naukowe Uniwersytetu Szczecińskiego, no. 663 (75/2011), Szczecin 2011.

\section{WPŁYW SPOŁECZNEJ ODPOWIEDZIALNOŚCI NA IMPLEMENTACJE ZRÓWNOWAŻONEGO ŁAŃCUCHA DOSTAW W WYBRANYCH PRZEDSIĘBIORSTWACH ENERGETYCZNYCH W POLSCE}

W artykule zostało przedstawione znaczenie, jakie na funkcjonowanie łąncucha dostaw w organizacjach wywierają koncepcja zrównoważonego rozwoju oraz koncepcja społecznej odpowiedzialności przedsiębiorstw (CSR, ang. Corporate Social Responsibility). Zauważono również związek pomiędzy biznesem społecznie odpowiedzialnym a zrównoważonym rozwojem, podkreśla to również wiele dokumentów międzynarodowych, między innymi normia ISO 26000, która jest przewodnikiem dla organizacji chcących wdrożyć te koncepcje do swojego funkcjonowania. Zasady społecznej odpowiedzialności, podobnie jak koncepcja zrówonoważonego rozwoju, z której się wywodzą, podkreślają równowagę pomiędzy sferą ekonomiczną, społeczną i etyczną działalności przedsiębiorstw. Niezbędne do właściwego i zrównoważonego zarządzania łańcuchem dostaw jest również zidentyfikowanie wszystkich grup interesariuszy (ang. stakeholder), z którymi organizacja wchodzi w interakcje oraz właściwa polityka firmy, która tworzy odpowiedzialną kulturę organizacyjną.

Przedsiębiorstwa, które starają się funkcjonować w sposób społecznie odpowiedzialny zwracają również uwagę na zasady prowadzenia działalności przez wszystkich interesariuszy, z którymi współpracują, dlatego coraz częściej wzrastają wymagania wobec nich. Coraz bardziej popularna dla współczesnych przedsiębiorstw staje się odpowiedzialność całego łańcucha dostaw oraz wdrożenie zrównoważonego łańcucha dostaw, dzięki czemu organizacje uzyskują dodatkowe korzyści długookresowe i w efekcie uzyskują przewagę konkurencyjną. Artykuł ukazuje również, w jaki sposób koncepcja społecznej odpowiedzialności może stać 
się podstawą tworzenia i wdrażania zrównoważonego łańcucha dostaw w organizacji i jak takie zrównoważone łańcuchy funkcjonują na wybranych przykładach przedsiębiorstw energetycznych w naszym kraju.

Słowa kluczowe: społeczna odpowiedzialność, zrównoważony rozwój, strategia CSR.

DOI: 10.7862/rz.2017.hss.59

Przestano do redakcji: kwiecień $2017 r$.

Przestano do druku: wrzesień 2017 r. 
